\title{
Blood transfusions may adversely affect survival outcomes of patients with lung cancer: a systematic review and meta-analysis
}

\author{
Sukjoo Cho ${ }^{1 \#}$, Jonghanne Park ${ }^{2 \#}$, Misuk Lee ${ }^{2}$, Dongyup Lee ${ }^{3}$, Horyun Choi ${ }^{4}$, Gahyun Gim ${ }^{5}$, \\ Leeseul Kim ${ }^{2}$, Cyra Y. Kang ${ }^{6}$, Youjin $\mathrm{Oh}^{2}$, Pedro Viveiros ${ }^{2}$, Elena Vagia ${ }^{2}$, Michael S. $\mathrm{Oh}^{2}$, \\ Geum Joon Cho ${ }^{7}$, Ankit Bharat ${ }^{8}$, Young Kwang Chae ${ }^{2,9}$
}

${ }^{1}$ Department of Pediatrics, University of South Florida Morsani College of Medicine, Tampa, FL, USA; ${ }^{2}$ Department of Medicine, Northwestern University Feinberg School of Medicine, Chicago, IL, USA; ${ }^{3}$ Department of Physical Medicine and Rehabilitation, Geisinger Health System, Danville, PA, USA; ${ }^{4}$ Department of Internal Medicine, University of Hawaii, Honolulu, HI, USA; ${ }^{5}$ Department of Medicine, St. Elizabeth's Medical Center, Tufts University School of Medicine, Boston, MA, USA; ' Department of Medicine, John H. Stroger, Jr. Hospital of Cook County, Chicago, IL, USA; ${ }^{7}$ Department of Obstetrics and Gynecology, Korea University College of Medicine, Seoul, Republic of Korea; ${ }^{8}$ Department of Surgery, Northwestern University Feinberg School of Medicine, Chicago, IL, USA; ${ }^{9}$ Robert H. Lurie Comprehensive Cancer Center of Northwestern University, Chicago, IL, USA

Contributions: (I) Conception and design: YK Chae, GJ Cho, S Cho, J Park, M Lee; (II) Administrative support: S Cho, M Lee; (III) Provision of study materials or patients: S Cho, J Park; (IV) Collection and assembly of data: S Cho, J Park; (V) Data analysis and interpretation: S Cho, J Park, YK Chae; (VI) Manuscript writing: All authors; (VII) Final approval of manuscript: All authors.

"These authors contributed equally to this work.

Correspondence to: Young Kwang Chae, MD, MPH, MBA. Associate Professor of Medicine, Northwestern University Feinberg School of Medicine, 645 North Michigan Avenue, Suite 1006, Chicago, IL 60611, USA. Email: young.chae@northwestern.edu.

Background: Despite common use in clinical practice, the impact of blood transfusions on prognosis among patients with lung cancer remains unclear. The purpose of the current study is to perform an updated systematic review and meta-analysis to evaluate the influence of blood transfusions on survival outcomes of lung cancer patients.

Methods: We searched PubMed, Embase, Cochrane Library, and Ovid MEDLINE for publications illustrating the association between blood transfusions and prognosis among people with lung cancer from inception to November 2019. Overall survival (OS) and disease-free survival (DFS) were the outcomes of interest. Pooled hazard ratios (HRs) with $95 \%$ confidence intervals (CIs) were computed using the randomeffects model. Study heterogeneity was evaluated with the $\mathrm{I}^{2}$ test. Publication bias was explored via funnel plot and trim-and-fill analyses.

Results: We included 23 cohort studies with 12,175 patients (3,027 cases and 9,148 controls) for metaanalysis. Among these records, 22 studies investigated the effect of perioperative transfusions, while one examined that of transfusions during chemotherapy. Two studies suggested the possible dose-dependent effect in accordance with the number of transfused units. In pooled analyses, blood transfusions deleteriously influenced both OS (HR=1.35, 95\% CI: 1.14-1.61, $\mathrm{P}<0.001, \mathrm{I}^{2}=0 \%$ ) and DFS (HR=1.46, 95\% CI: 1.15-1.86, $\left.\mathrm{P}=0.001, \mathrm{I}^{2}=0 \%\right)$ of people with lung cancer. No evidence of significant publication bias was detected in funnel plot and trim-and-fill analyses (OS: $\mathrm{HR}=1.26,95 \% \mathrm{CI}: 1.07-1.49, \mathrm{P}=0.006$; DFS: HR=1.35, 95\% CI: 1.08-1.69, $\mathrm{P}=0.008)$.

Conclusions: Blood transfusions were associated with decreased survival of patients with lung cancer.

Keywords: Transfusion; cancer; lung cancer; survival; meta-analysis

Submitted Aug 10, 2020. Accepted for publication Jan 18, 2021.

doi: $10.21037 /$ tlcr-20-933

View this article at: http://dx.doi.org/10.21037/tlcr-20-933 


\section{Introduction}

Lung cancer has the highest mortality rate among tumor entities in the United States, accounting for a quarter of all cancer deaths annually (1). Patients with lung cancer may require blood transfusions due to cancer-induced anemia, blood loss during surgery, or bone marrow suppression caused by chemoradiation (2). Despite common use in clinical practice, the impact of blood transfusions on prognosis among patients with lung cancer remains unclear. Over the past 35 years, efforts have been made to discern the relationship between blood transfusions and survival outcomes [e.g., overall survival (OS) and disease-free survival (DFS)] of lung cancer patients. Of note, there have been long-standing concerns on the associated risk, including possible contamination by undetected malignant cells in the blood products $(3,4)$. In addition, the potential immunomodulatory effect of blood transfusions has been explored (5). It has been hypothesized that blood transfusions may suppress the antitumor immunosurveillance and promote growth of tumor cells (6). Previous efforts to elucidate the relationship between transfusions and cancer recurrence have focused primarily on other types of cancer such as colorectal cancer (7). We thus performed an updated systematic review and meta-analysis to evaluate the influence of blood transfusions on survival outcomes of lung cancer patients. The following article is presented in accordance with the Preferred Reporting Items for Systematic Reviews and Meta-Analyses (PRISMA) reporting checklist (8) (available at http://dx.doi.org/10.21037/tlcr-20-933).

\section{Methods}

\section{Data sources and search strategy}

We searched PubMed, Embase, Cochrane Library, and Ovid MEDLINE for relevant published or unpublished studies from inception to November 2019. Detailed search strategy is shown in Table S1. The electronic search strategy was supplemented by manually reviewing references of identified articles including recent reviews. We imposed no restrictions on the language, the study period, and the sample size.

\section{Study selection and outcome definition}

Studies which met the following criteria were eligible for meta-analysis: (I) conducted before November 2019;
(II) enrolling patients diagnosed with lung cancer; (III) comparing prognosis between transfused and nontransfused patients. All types of lung cancer and all TNM stages were included. All types of blood products were considered. The outcomes of interest were OS and DFS. We only selected the studies reporting the hazard ratio (HR) for OS or DFS or providing sufficient data to calculate them (9). We screened search results by assessing titles and abstracts, eliminated duplicates, reviewed fulltext articles if available, and determined their inclusion independently. Disagreements were settled by consensus among all contributors.

\section{Data extraction and quality assessment}

OS, DFS, and their HR with the $95 \%$ CI from included studies were extracted using a standardized form. Other compiled study characteristics were as follows: the first author, the publication year, the location of study, the enrollment period, the sample size, the type and stage of cancer, and the type of transfused blood components. Given lack of randomized-controlled trials on the current topic, we utilized the Newcastle-Ottawa Scale (NOS) to evaluate the quality of collected cohort studies. The elements of the NOS are described fully in Table S2.

\section{Data synthesis and statistical analysis}

We applied the random-effects model to analyze primary endpoints and presented combined HRs for OS and DFS with their $95 \%$ CIs as summary statistics. Pooled HRs were calculated with the restricted maximum-likelihood estimator. The results were illustrated in forest plots. Statistical heterogeneity was quantified using the $\mathrm{I}^{2}$ statistics (10). Publication bias was examined through funnel plots, along with the trim-and-fill method. Two-sided $\mathrm{P}<0.05$ was considered to achieve statistical significance. Subgroup analyses of OS and DFS in patients with lung cancer who received transfusions during surgical resection to detect possible difference between surgical and nonsurgical blood transfusions. All statistical computations were performed on R 3.5.1 using the package 'metafor' 2.1-0.

\section{Results}

\section{Search results}

We identified 843 citations by searching electronic 


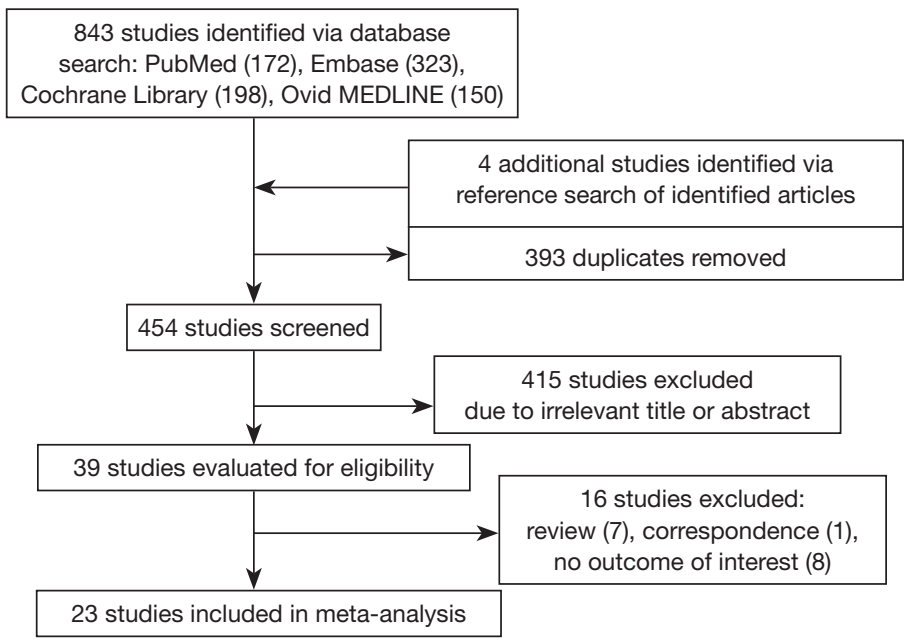

Figure 1 Flow diagram of study selection.

databases including PubMed ( $\mathrm{n}=172)$, Embase ( $\mathrm{n}=323)$, Cochrane Library ( $\mathrm{n}=198)$, and Ovid MEDLINE ( $\mathrm{n}=150)$ (Figure 1). Four studies were added by investigating reference lists of the initially identified articles. After evaluating titles and abstracts, we excluded 393 duplicates and 415 irrelevant articles. Among the remaining 39 studies, 16 studies were removed given that they were review $(n=7)$ or correspondence $(n=1)$ articles or lacked the outcome of interest $(\mathrm{n}=8)$. The detailed characteristics of 16 excluded studies are summarized in Table S3. Consequently, 23 studies qualified for subsequent meta-analysis.

\section{Study characteristics}

The summaries of individual studies are listed in Table 1. All the included records were cohort studies published from 1984 to 2019 , including 12,175 patients (3,027 cases and 9,148 controls) in total. Among these trials, ten were conducted in the United States, three in Italy, two in Spain, one in Germany, one in Finland, one in Poland, one in the United Kingdom, one in France, one in China, one Greece, and one in Turkey. The sample size for each of the studies ranged from 105 to 4,847 . The pathology and the disease stage of lung cancer varied. Diverse blood products such as whole blood, packed red blood cells, and fresh frozen plasma were transfused. One study compared the effects of allogeneic and autologous transfusions on survival outcomes of patients with non-small cell lung cancer (NSCLC) (23).

Perioperative transfusions were addressed in all included studies except for a recent one dealing with transfusions during chemotherapy (33). Nineteen studies imposed no restriction on the extent of resection, while three studies only investigated patients with early-stage lung cancer who underwent lobectomy $(11,22,30)$. A large U.S. cohort study included records of surgical approaches such as minimally invasive thoracic surgery, although no further analysis was performed with the data (32).

Of note, there exist two recent publications suggesting the possible dose-dependent effect of packed red blood cells on long-term cancer outcomes $(31,32)$. Both articles demonstrated a dose-response relationship between blood transfusions and survival outcomes, particularly in patients who received at least two units of red cells.

\section{Survival analysis}

As shown in the forest plot of Figure 2, we extracted HRs for OS from 20 records (11-13,15,17-27,29-33). The pooled HR from the random-effects model favored non-transfused patients over transfused patients for OS (HR=1.35, 95\% CI: 1.14-1.61, $\mathrm{P}<0.001)$. The corresponding $\mathrm{I}^{2}$ test found no significant heterogeneity among the studies $\left(\mathrm{I}^{2}=0 \%\right)$.

HRs for DFS were compiled from 13 articles (11,1317,19,22,28,30-33). The forest plot of Figure 3 illustrates HRs from each of the studies as well as the net HR. The combined results from the random effects model showed that transfused patients had worse DFS than non-transfused patients (HR=1.46, 95\% CI: $1.15-1.86, \mathrm{P}=0.001)$. There was no evidence of study heterogeneity $\left(\mathrm{I}^{2}=0 \%\right)$.

To discern any difference between surgical and nonsurgical blood transfusions, in addition, we performed subgroup analyses of OS and DFS in patients who 
Table 1 Characteristics of included studies

\begin{tabular}{|c|c|c|c|c|c|c|c|}
\hline First author & Year & Location & $\begin{array}{c}\text { Enrollment } \\
\text { period }\end{array}$ & Size & Cancer pathology & Stage & Blood components \\
\hline Tartter (11) & 1984 & USA & $1966-1980$ & 165 & NSCLC & I (N0) & NA \\
\hline Hyman (12) & 1985 & USA & $1971-1979$ & 105 & Any lung cancer & $I-I I$ & WB, PRBC \\
\hline Pastorino (13) & 1986 & Italy & 1974-1979 & 283 & NSCLC & $\mathrm{IA}$ & WB, PRBC \\
\hline Little (16) & 1990 & USA & 1977-1986 & 117 & NSCLC & 1 & WB, PRBC \\
\hline Pena (17) & 1992 & USA & 1980-1984 & 127 & NSCLC & I-II & Any component \\
\hline Zimmermann (18) & 1993 & Germany & $1976-1985$ & 224 & Any lung cancer & I-III & NA \\
\hline Nosotti (22) & 2003 & Italy & 1995-2000 & 281 & NSCLC & 1 & Any component \\
\hline Rzyman (23) & 2003 & Poland & 1993-1997 & 493 & NSCLC & I-IV & WB, PRBC \\
\hline Ghosh (24) & 2004 & UK & 1996-2003 & 329 & $A C, S C C$ & I-IIIB & NA \\
\hline Peñalver (25) & 2005 & Spain & 1969-2000 & 856 & NSCLC & I & WB, PRBC \\
\hline Berardi (26) & 2005 & Italy & $1996-2001$ & 439 & NSCLC & I-IIIB & NA \\
\hline Thomas (27) & 2007 & France & 1993-2002 & 367 & Any lung cancer & I-IV & PRBC, PLT, FFP, coagulation factor VIII \\
\hline Chen (28) & 2007 & China & 1993-2002 & 280 & NSCLC & $|-| I \mid$ & NA \\
\hline
\end{tabular}

NSCLC, non-small cell lung cancer; NA, not available; WB, whole blood; PRBC, packed red blood cells; AC, adenocarcinoma; SCC, squamous cell carcinoma; FFP, fresh frozen plasma; PLT, platelets.

underwent resection of lung cancer. The analyses showed unchanged results: perioperative blood transfusions were associated with shortened OS (HR=1.35, 95\% CI: 1.13 1.62, $\left.\mathrm{P}=0.001, \mathrm{I}^{2}=0 \%\right)$ and DFS (HR=1.46, 95\% CI: $1.13-$ $\left.1.88, \mathrm{P}=0.004, \mathrm{I}^{2}=0 \%\right)$.

In short, blood transfusions deleteriously influenced both OS and DFS of people with lung cancer. Such results did not change after exclusively including surgical blood transfusions.

\section{Publication bias}

The risk of publication bias was examined by inspecting funnel plots for OS and DFS, respectively. Evident asymmetry was observed in both plots (Figure $3 A, B$ ). Correspondingly, we performed the trim-and-fill analyses for both outcomes, which computed potential four missing studies for OS and four for DFS (Figure 3C,D). However, the adjustments indicated only slight alterations for both estimates (OS: HR=1.26, 95\% CI: 1.07-1.49, $\mathrm{P}=0.006$; DFS: $\mathrm{HR}=1.35,95 \%$ CI: $1.08-1.69, \mathrm{P}=0.008)$.

\section{Discussion}

We conducted a systematic review and meta-analysis of 

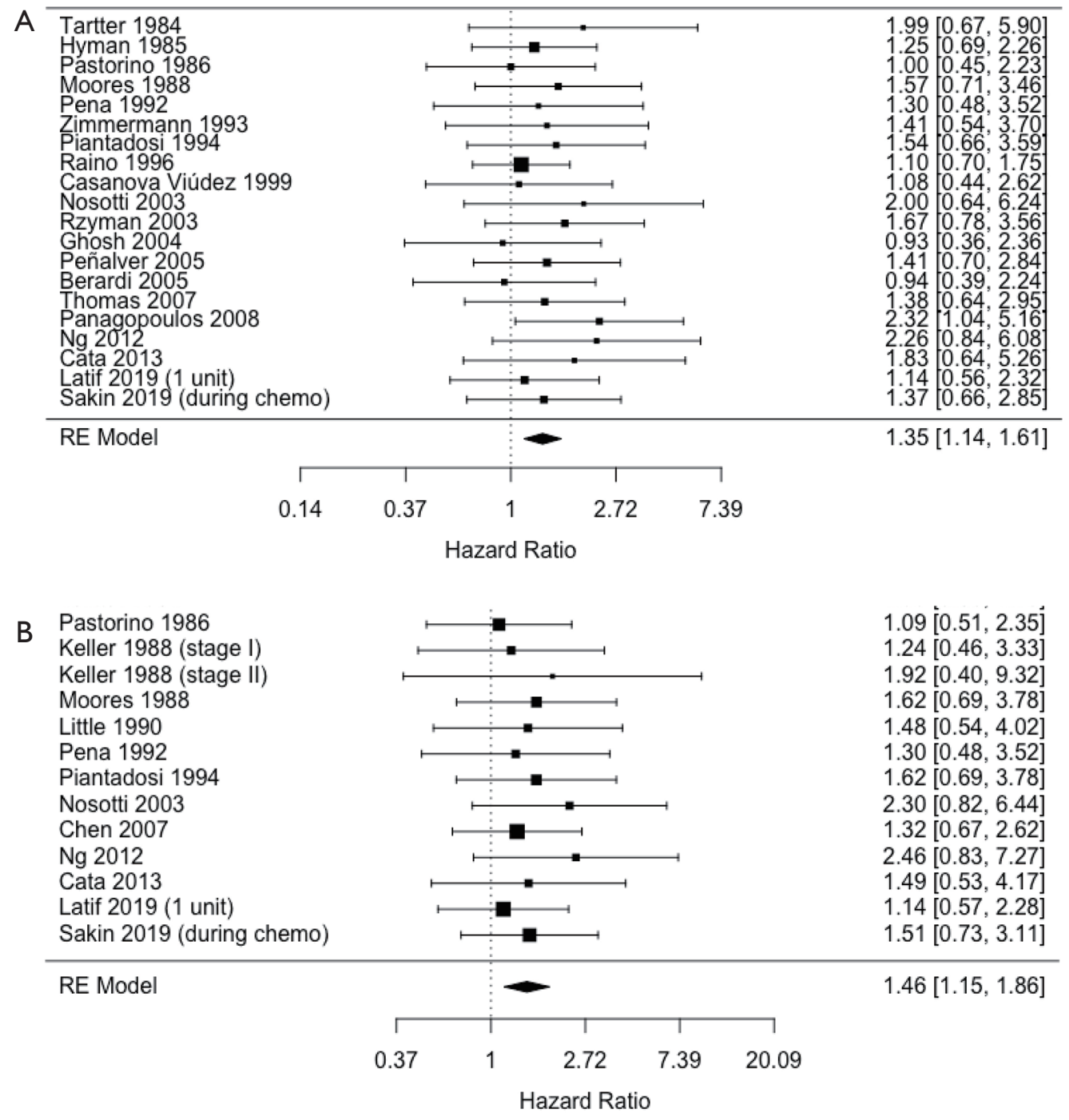

Figure 2 Forest plots showing the effect of blood transfusions on (A) overall survival (OS) and (B) disease-free survival (DFS).

23 cohort studies that examined the influence of blood transfusions on survival outcomes of people with lung cancer. The results showed that the receipt of blood components shortened both OS and DFS of patients with lung cancer. Our study is the most up-to-date and comprehensive systematic review and meta-analysis on the present topic. In comparison to prior meta-analyses (34-36), our study encompassed four recent trials (31-33) with resultant increase in the sample size $(\mathrm{n}=12,175)$.

Of note, two of these added studies demonstrated potential dose-dependent association between the amount of blood transfusions and survival outcomes of patients with lung cancer $(31,32)$, which was not attested in preceding studies $(13,14,16,22)$. A U.S. cohort study including 636 patients who underwent surgery for NSCLC showed that the 5-year recurrence-free survival decreased proportionately with the number of units transfused (31). More recently, another U.S. cohort study involving 5,709 patients undergoing NSCLC resection described that the increasing volume of blood transfusions was associated with worse OS, DFS, and recurrence (32). Given that features of both studies coincided in cancer type and stage (i.e., stage IIIIA NSCLC) as well as blood components (i.e., packed red blood cells), efforts to conduct a subgroup analysis for the potential dose-response relationship between the quantity of blood transfusions and survival outcomes of lung cancer 

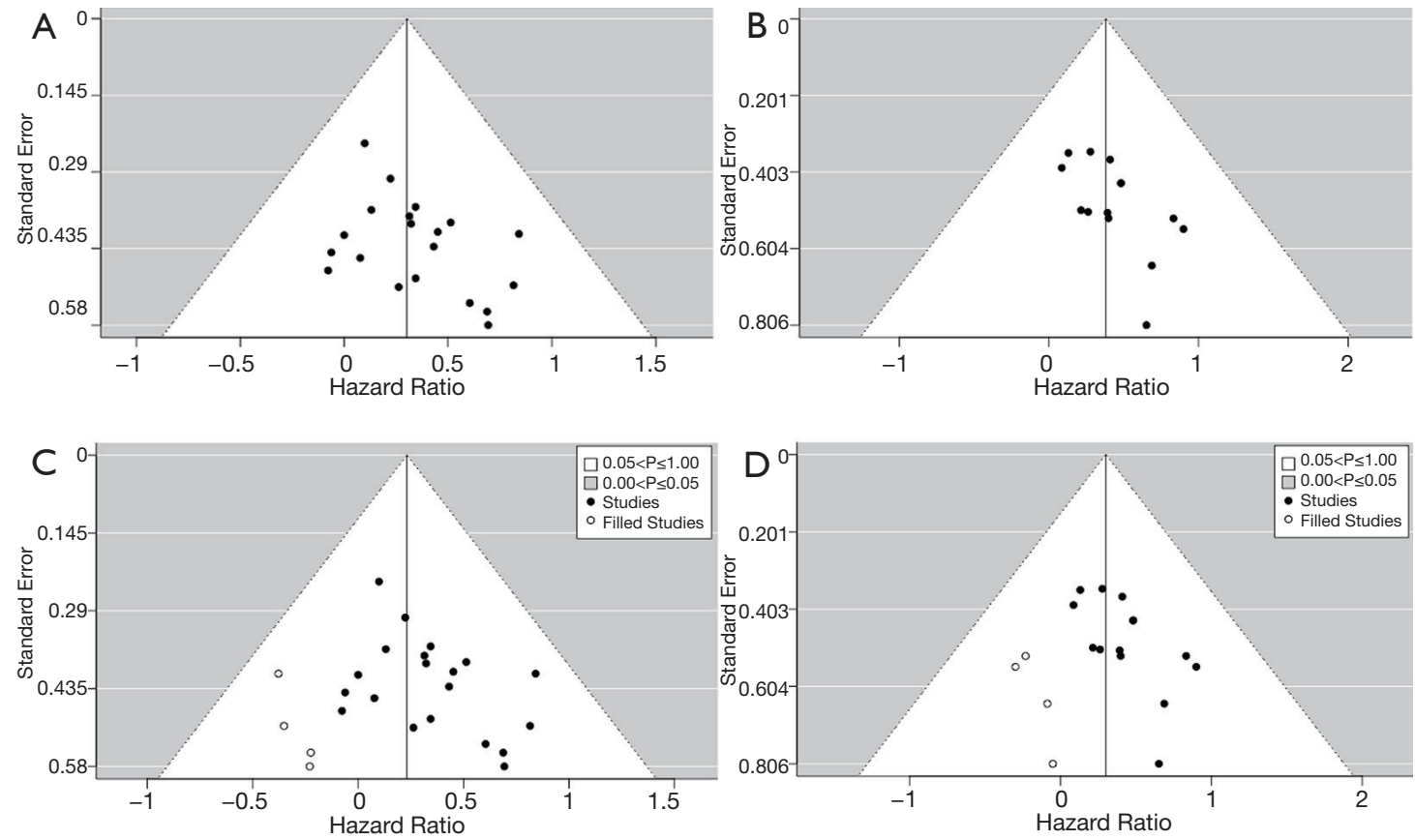

Figure 3 Assessment of publication bias: funnel plots for (A) overall survival (OS) and (B) disease-free survival (DFS); trim-and-fill analyses for (C) OS and (D) DFS.

patients. However, we were unable to combine the results of two studies due to discrepant cut-off values for the transfused units among individual studies.

Nonetheless, these recent findings that larger volumes of blood transfusions were associated with worse prognosis of lung cancer are worthy of being noted given stronger evidence in another type of cancer. In a landmark metaanalysis evaluating the effect of perioperative blood transfusions on recurrence of colorectal cancer (7), recurrence risks increased by 40,69 , and $102 \%$ were observed with 1 to 2,3 to 4 , and 5 or more units of blood transfusions, respectively. Furthermore, a more recent study utilizing propensity score matching to minimize possible imbalances in patient characteristics showed a significant dose-response relationship between transfused units and overall mortality following colorectal cancer resection (37). Likewise, more evidence can be gathered in lung cancer if more studies using proper statistical techniques are performed.

Of note, our study also included a recent study investigating the impact of blood transfusions on nonsurgical patients with lung cancer for the first time (33). Unlike prior studies mostly focusing on early-stage lung cancer requiring surgical resection, this study addressed advanced stage lung cancer requiring chemotherapy. In the analysis, blood transfusions were associated with significantly shorter DFS and OS, particularly in patients with adenocarcinoma. Such results suggest that blood transfusions per se might be more related to cancer outcomes, rather than operational complexity and aggressiveness of tumors.

One proposed mechanism for this association is direct transmission of the concealed tumor cell in the blood products. The idea of cancer seeding has been explored as a probable rationale for decades, classically in the context of autotransfusion in cancer surgery (3). The theoretical fear of re-infusing malignant cells directly into the bloodstream was fueled by a case report in which unfiltered tumor cells were detected in the intraoperatively salvaged blood (38). These concerns were significantly resolved by multiple trials investigating the safety of cell salvage in cancer surgery where leukoreduction filters were used (39-44). However, the plausibility of such idea was further supported by the reports of long-term leukocyte microchimerism after blood transfusions (45-47) and transferred malignancies through various organ transplantations $(4,48-52)$. Of note, two individuals who had received renal transplants from the same cadaver donor developed fatal melanoma in their donated kidneys (48). These melanomas were considered secondary as the donor had been diagnosed with the same condition at an early, localized stage and treated successfully with curative resection 16 years before 
her death. One interpretation of this report is that the donated kidneys had contained dormant melanoma cells, which later grew out into clinically apparent malignancies in the immunosuppressed recipients (53). Such speculation strongly supports the theory of contamination by unfound cancer cells. Moreover, there have been scattered reports of transmitted malignancies via needles (54) or surgical instruments (55), which suggest the capability of tumor cells to survive even in the healthy recipients (56).

Another putative rationale is the immunosuppressive effect of allogeneic blood transfusions, also known as transfusion-related immunomodulation (TRIM). This phenomenon was first described in the reports illustrating the influence of pretransplant transfusions on allograft survival among patients who underwent renal transplantation (57-59). Of note, infusing blood products into these patients improved kidney-graft survival. In addition, there was a dose-response relationship between the amount of transfusions and long-term transplant survival. The same phenomenon has been observed in transplantations of heart (60) and lung (61), although controversies persist (62). The recognition of this transfusion-induced immunosuppression prompted concerns that blood transfusions may increase the risk of cancer recurrence after curative surgery (63). Over the past four decades, it has been speculated that blood transfusions may attribute to cancer progression by dampening recipients' immunity (64).

Such speculation has been further corroborated by the emerging cancer immunoediting theory (53). This theory insists that tumors continuously proliferate and mutate against the immune system. In case of immunosuppression, therefore, tumors escape the anti-cancer surveillance more readily. This plausibility was substantiated in studies regarding various immunocompromising conditions. For example, it was shown that lifelong use of immunosuppressants in transplant patients led to significant increases in more than 30 different malignancies (65-70). Escalated risks for various cancers were also detected among people with human immunodeficiency virus-acquired immunodeficiency syndrome (HIV-AIDS) (71-73). Added to these acquired immunodeficient conditions, moreover, a recent study discovered elevated cancer incidence in innate primary immunodeficiencies as well (74).

However, the exact mechanism of TRIM remains still unclear. Suggested mediators for TRIM include conveyed mononuclear cells, leukocyte-derived cytokines and/or soluble human leukocyte antigen (HLA) peptides $(5,6)$. In particular, transferred leukocytes has been contemplated to disturb the host's immune system (63), as in graft-versushost disease (GVHD) (75). In other words, the equilibrium between tumors and the anti-tumor immunosurveillance might be disturbed by donated white cells, thereby causing clinically apparent cancer (53). However, there has been emerging evidence that leukoreduction filters had no effect on TRIM. For instance, the use of leukocyte-depleted red cells did not prevent either GVHD $(76,77)$ or long-term transfusion-associated microchimerism (45). According to some randomized trials, moreover, leukoreduction was not associated with improved survival outcomes of patients with colon cancer (78-81). These findings were also concordant with one of the included studies in our meta-analysis. A retrospective study addressing 361 U.S. patients with stage I NSCLC found that transfusion of leukoreduced blood was associated with worse DFS and OS when compared with no transfusion (30).

To understand the effect of blood transfusions on cancer outcomes, attention was given to perioperative transfusions during curative surgery in general, measuring relapse of cancer. Unlike these strategies, scattered investigations estimated cancer incidence in people who received transfusions to address this issue. For example, a Scandinavian cohort study showed marked increase in overall cancer incidence among transfusion recipients, specifically within six months after transfusions (82). A U.S. population-based case-control study also detected increased risk of all cancer, particularly within a year after transfusions (83). Although both studies explained such results by incipient cancer that caused anemia requiring transfusions, they did not fully exclude the possible effect of blood transfusions on new cancer diagnoses.

We also found a report that analyzed data on peripartum transfusions, where the likelihood of predisposing comorbidities and undetected cancer supposedly diminishes (84). In this retrospective cohort study with the 30 -year follow-up, cancer incidence in 621 women who received transfusions during childbirth was compared with that in 1,216 women who did not. The results showed no significant difference between the two groups. However, our recent study utilizing a national cohort of 270,529 pregnant women in South Korea showed that receipt of 3 or more units of blood transfusions during delivery was associated with significantly elevated risk of developing cancer (85). Such elevated risk was observed in brain, lung, ovarian, and gallbladder malignancies. Furthermore, the difference between transfused and non-transfused groups was seen 
both at the first and second years after delivery. Despite retrospective and observational nature, our study strongly suggests the plausibility that blood transfusions might cause cancer development given a complete and representative dataset from a national registry.

Several limitations to this analysis need to be acknowledged. Firstly, in terms of addressing the relationship between transfusions and survival among patients with lung cancer, it is impossible to perform randomized trials for obvious ethical reasons. All available publications were conducted retrospectively. Such retrospective nature is subject to the effects of various confounding factors which are unavailable in our collected data. For example, our data did not include information on postoperative complications, which could have influenced both transfusion rates and mortality rates of patients who underwent major thoracic surgery (86). Secondly, although the $\mathrm{I}^{2}$ statistics failed to detect quantitative heterogeneity among the included studies, we could still observe qualitative disparities, including types and stages of cancer. Details of transfusions such as the type of blood products and the number of transfused units also varied. Such differences could have affected the results of our analysis.

\section{Conclusions}

In conclusion, our findings suggest that blood transfusions may adversely influence survival of patients with lung cancer. Although the exact mechanism remains unclear, there exist concerns for direct transmission of tumor cells as well as the immunomodulatory effect of transfusions. If these hypotheses could be scientifically validated, it would have significant implications for public health and future policies. Therefore, prospective studies and in vivo experiments attesting such speculations are warranted. Moreover, restrictive transfusion strategies should be instituted while caring for patients with cancer.

\section{Acknowledgments}

A part of the manuscript (abstract and poster) was presented at the American Association for Cancer Research (AACR) Annual Meeting 2020.

Funding: None.

\section{Footnote}

Reporting Checklist: The authors have completed the
PRISMA reporting checklist. Available at http://dx.doi. org/10.21037/tlcr-20-933

Conflicts of Interest: All authors have completed the ICMJE uniform disclosure form (available at http://dx.doi. org/10.21037/tlcr-20-933). The authors have no conflicts of interest to declare.

Etbical Statement: The authors are accountable for all aspects of the work in ensuring that questions related to the accuracy or integrity of any part of the work are appropriately investigated and resolved.

Open Access Statement: This is an Open Access article distributed in accordance with the Creative Commons Attribution-NonCommercial-NoDerivs 4.0 International License (CC BY-NC-ND 4.0), which permits the noncommercial replication and distribution of the article with the strict proviso that no changes or edits are made and the original work is properly cited (including links to both the formal publication through the relevant DOI and the license). See: https://creativecommons.org/licenses/by-nc-nd/4.0/.

\section{References}

1. Siegel RL, Miller KD, Jemal A. Cancer statistics, 2019. CA Cancer J Clin 2019;69:7-34.

2. Dicato M, Plawny L, Diederich M. Anemia in cancer. Ann Oncol 2010;21 Suppl 7:vii167-72.

3. Waters JH, Donnenberg AD. Blood salvage and cancer surgery: should we do it? Transfusion 2009;49:2016-8.

4. Winter TC, Keller PR, Lee FT Jr, et al. Donor-derived malignancy: transmission of small-cell lung cancer via renal transplantation. J Ultrasound Med 2001;20:559-62.

5. Vamvakas EC, Blajchman MA. Transfusion-related immunomodulation (TRIM): an update. Blood Rev 2007;21:327-48.

6. Cata JP, Wang H, Gottumukkala V, et al. Inflammatory response, immunosuppression, and cancer recurrence after perioperative blood transfusions. Br J Anaesth 2013;110:690-701.

7. Amato A, Pescatori M. Perioperative blood transfusions for the recurrence of colorectal cancer. Cochrane Database Syst Rev 2006;2006:CD005033.

8. Moher D, Liberati A, Tetzlaff J, et al. Preferred reporting items for systematic reviews and meta-analyses: the PRISMA statement. PLoS Med 2009;6:e1000097.

9. Tierney JF, Stewart LA, Ghersi D, et al. Practical methods 
for incorporating summary time-to-event data into metaanalysis. Trials 2007;8:16.

10. Higgins JP, Thompson SG, Deeks JJ, et al. Measuring inconsistency in meta-analyses. BMJ 2003;327:557-60.

11. Tartter PI, Burrows L, Kirschner P. Perioperative blood transfusion adversely affects prognosis after resection of Stage I (subset N0) non-oat cell lung cancer. J Thorac Cardiovasc Surg 1984;88:659-62.

12. Hyman NH, Foster RS Jr, DeMeules JE, et al. Blood transfusions and survival after lung cancer resection. Am J Surg 1985;149:502-7.

13. Pastorino U, Valente M, Cataldo I, et al. Perioperative blood transfusion and prognosis of resected stage Ia lung cancer. Eur J Cancer Clin Oncol 1986;22:1375-8.

14. Keller SM, Groshen S, Martini N, et al. Blood transfusion and lung cancer recurrence. Cancer 1988;62:606-10.

15. Moores DW, Piantadosi S, McKneally MF. Effect of perioperative blood transfusion on outcome in patients with surgically resected lung cancer. Ann Thorac Surg 1989;47:346-51.

16. Little AG, Wu HS, Ferguson MK, et al. Perioperative blood transfusion adversely affects prognosis of patients with stage I non-small-cell lung cancer. Am J Surg 1990;160:630-2; discussion 633.

17. Pena CM, Rice TW, Ahmad M, et al. Significance of perioperative blood transfusions in patients undergoing resection of stage I and II non-small-cell lung cancers. Chest 1992;102:84-8.

18. Zimmermann T, Dobroschke J, Becker C, et al. Effect of perioperative donor blood transfusion on prognosis of bronchial cancer. Langenbecks Arch Chir 1993;378:145-9.

19. Piantadosi S, Moores DW, McKneally MF. The adverse effect of perioperative blood transfusion in lung cancer. Chest 1994;106:382S-4S.

20. Rainio P, Bloigu R, Satta J, et al. Ten-year survival after resection for lung carcinoma. Effect of blood transfusion and tumour stage on outcome. Scand J Thorac Cardiovasc Surg 1996;30:87-91.

21. Casanova Viúdez J, Marinan Gorospe M, Sobradillo Pena V, et al. The effect of peroperative transfusion on survival in resected lung carcinomas. Arch Bronconeumol 1999;35:417-21.

22. Nosotti M, Rebulla P, Riccardi D, et al. Correlation between perioperative blood transfusion and prognosis of patients subjected to surgery for stage I lung cancer. Chest 2003;124:102-7.

23. Rzyman W, Dziadziuszko R, Skokowski J, et al. The influence of blood transfusion on survival in operated non- small cell lung cancer patients. J Thorac Cardiovasc Surg 2003;126:755-60.

24. Ghosh S, Ahmed K, Hopkinson DN, et al. Pulmonary adenocarcinoma is associated with poor long-term survival after surgical resection. Effect of allogeneic blood transfusion. Cancer 2004;101:2058-66.

25. Peñalver JC, Padilla J, Jorda C, et al. Use of blood products in patients treated surgically for stage I non-small cell lung cancer. Arch Bronconeumol 2005;41:484-8.

26. Berardi R, Brunelli A, Tamburrano T, et al. Perioperative anemia and blood transfusions as prognostic factors in patients undergoing resection for non-small cell lung cancers. Lung Cancer 2005;49:371-6.

27. Thomas P, Michelet P, Barlesi F, et al. Impact of blood transfusions on outcome after pneumonectomy for thoracic malignancies. Eur Respir J 2007;29:565-70.

28. Chen JH, Jiao SC. The relationship between prognosis and perioperatvie allogeneic blood transfusions in 280 non-small cell lung cancer patients. Chin J Clin Oncol 2007;34:632-5.

29. Panagopoulos ND, Karakantza M, Koletsis E, et al. Influence of blood transfusions and preoperative anemia on long-term survival in patients operated for non-small cell lung cancer. Lung Cancer 2008;62:273-80.

30. Ng T, Ryder BA, Chern H, et al. Leukocyte-depleted blood transfusion is associated with decreased survival in resected early-stage lung cancer. J Thorac Cardiovasc Surg 2012;143:815-9.

31. Cata JP, Chukka V, Wang H, et al. Perioperative blood transfusions and survival in patients with non-small cell lung cancer: a retrospective study. BMC Anesthesiol 2013;13:42.

32. Latif MJ, Tan KS, Molena D, et al. Perioperative blood transfusion has a dose-dependent relationship with disease recurrence and survival in patients with non-small cell lung cancer. J Thorac Cardiovasc Surg 2019;157:2469-77.e10.

33. Sakin A, Sahin S, Yasar N, et al. Prognostic impact of blood transfusion in patients with metastatic non-small cell lung cancer receiving chemotherapy. Lung Cancer 2019;133:38-44.

34. Vamvakas EC. Perioperative blood transfusion and cancer recurrence: meta-analysis for explanation. Transfusion 1995;35:760-8.

35. Wang T, Luo L, Huang H, et al. Perioperative blood transfusion is associated with worse clinical outcomes in resected lung cancer. Ann Thorac Surg 2014;97:1827-37.

36. Luan H, Ye F, Wu L, et al. Perioperative blood transfusion adversely affects prognosis after resection of lung cancer: 
a systematic review and a meta-analysis. BMC Surg 2014;14:34.

37. Wu HL, Tai YH, Lin SP, et al. The Impact of Blood Transfusion on Recurrence and Mortality Following Colorectal Cancer Resection: A Propensity Score Analysis of 4,030 Patients. Sci Rep 2018;8:13345.

38. Yaw PB, Sentany M, Link WJ, et al. Tumor cells carried through autotransfusion. Contraindication to intraoperative blood recovery? JAMA 1975;231:490-1.

39. Catling S, Williams S, Freites O, et al. Use of a leucocyte filter to remove tumour cells from intra-operative cell salvage blood. Anaesthesia 2008;63:1332-8.

40. Connor JP, Morris PC, Alagoz T, et al. Intraoperative autologous blood collection and autotransfusion in the surgical management of early cancers of the uterine cervix. Obstet Gynecol 1995;86:373-8.

41. Stoffel JT, Topjian L, Libertino JA. Analysis of peripheral blood for prostate cells after autologous transfusion given during radical prostatectomy. BJU Int 2005;96:313-5.

42. Hirano T, Yamanaka J, Iimuro Y, et al. Long-term safety of autotransfusion during hepatectomy for hepatocellular carcinoma. Surg Today 2005;35:1042-6.

43. Nieder AM, Manoharan M, Yang Y, et al. Intraoperative cell salvage during radical cystectomy does not affect longterm survival. Urology 2007;69:881-4.

44. Kang R, Seath BE, Huang V, et al. Impact of Autologous Blood Transfusion on Survival and Recurrence among Patients Undergoing Partial Hepatectomy for Colorectal Cancer Liver Metastases. J Am Coll Surg 2019;228:902-8.

45. Lee TH, Paglieroni T, Ohto H, et al. Survival of donor leukocyte subpopulations in immunocompetent transfusion recipients: frequent long-term microchimerism in severe trauma patients. Blood 1999;93:3127-39.

46. Utter GH, Owings JT, Lee TH, et al. Blood transfusion is associated with donor leukocyte microchimerism in trauma patients. J Trauma 2004;57:702-7; discussion 7-8.

47. Lee TH, Paglieroni T, Utter GH, et al. High-level long-term white blood cell microchimerism after transfusion of leukoreduced blood components to patients resuscitated after severe traumatic injury. Transfusion 2005;45:1280-90.

48. MacKie RM, Reid R, Junor B. Fatal melanoma transferred in a donated kidney 16 years after melanoma surgery. $\mathrm{N}$ Engl J Med 2003;348:567-8.

49. Kauffman HM, McBride MA, Cherikh WS, et al. Transplant tumor registry: donors with central nervous system tumors1. Transplantation 2002;73:579-82.

50. Buell JF, Beebe TM, Trofe J, et al. Donor transmitted malignancies. Ann Transplant 2004;9:53-6.

51. Spiro IJ, Yandell DW, Li C, et al. Brief report: lymphoma of donor origin occurring in the porta hepatis of a transplanted liver. N Engl J Med 1993;329:27-9.

52. Bodó I, Peters M, Radich JP, et al. Donor-derived acute promyelocytic leukemia in a liver-transplant recipient. $\mathrm{N}$ Engl J Med 1999;341:807-13.

53. Schreiber RD, Old LJ, Smyth MJ. Cancer immunoediting: integrating immunity's roles in cancer suppression and promotion. Science 2011;331:1565-70.

54. Gugel EA, Sanders ME. Needle-stick transmission of human colonic adenocarcinoma. N Engl J Med 1986;315:1487.

55. Gärtner HV, Seidl C, Luckenbach C, et al. Genetic analysis of a sarcoma accidentally transplanted from a patient to a surgeon. N Engl J Med 1996;335:1494-6.

56. Edgren G, Hjalgrim H, Reilly M, et al. Risk of cancer after blood transfusion from donors with subclinical cancer: a retrospective cohort study. Lancet 2007;369:1724-30.

57. Opelz G, Sengar DP, Mickey MR, et al. Effect of blood transfusions on subsequent kidney transplants. Transplant Proc 1973;5:253-9.

58. Opelz G, Terasaki PI. Improvement of kidney-graft survival with increased numbers of blood transfusions. $\mathrm{N}$ Engl J Med 1978;299:799-803.

59. Sanfilippo F, Spees EK, Vaughn WK. The timing of pretransplant transfusions and renal allograft survival. Transplantation 1984;37:344-50.

60. Fernández FG, Jaramillo A, Ewald G, et al. Blood transfusions decrease the incidence of acute rejection in cardiac allograft recipients. J Heart Lung Transplant 2005;24:S255-61.

61. Mason DP, Little SG, Nowicki ER, et al. Temporal pattern of transfusion and its relation to rejection after lung transplantation. J Heart Lung Transplant 2009;28:558-63.

62. Ong LP, Sachdeva A, Ramesh BC, et al. Lung Transplant With Cardiopulmonary Bypass: Impact of Blood Transfusion on Rejection, Function, and Late Mortality. Ann Thorac Surg 2016;101:512-9.

63. Gantt CL. Red blood cells for cancer patients. Lancet 1981;2:363.

64. Brand A. Immunological aspects of blood transfusions. Transpl Immunol 2002;10:183-90.

65. Engels EA, Pfeiffer RM, Fraumeni JF Jr, et al. Spectrum of cancer risk among US solid organ transplant recipients. JAMA 2011;306:1891-901.

66. Shiels MS, Pfeiffer RM, Hall HI, et al. Proportions of Kaposi sarcoma, selected non-Hodgkin lymphomas, and 
cervical cancer in the United States occurring in persons with AIDS, 1980-2007. JAMA 2011;305:1450-9.

67. Opelz G, Dohler B. Lymphomas after solid organ transplantation: a collaborative transplant study report. Am J Transplant 2004;4:222-30.

68. Leblond V, Davi F, Charlotte F, et al. Posttransplant lymphoproliferative disorders not associated with EpsteinBarr virus: a distinct entity? J Clin Oncol 1998;16:2052-9.

69. Birkeland SA, Storm HH, Lamm LU, et al. Cancer risk after renal transplantation in the Nordic countries, 19641986. Int J Cancer 1995;60:183-9.

70. List AF, Greco FA, Vogler LB. Lymphoproliferative diseases in immunocompromised hosts: the role of Epstein-Barr virus. J Clin Oncol 1987;5:1673-89.

71. Clifford GM, Polesel J, Rickenbach M, et al. Cancer risk in the Swiss HIV Cohort Study: associations with immunodeficiency, smoking, and highly active antiretroviral therapy. J Natl Cancer Inst 2005;97:425-32.

72. Shiels MS, Cole SR, Kirk GD, et al. A meta-analysis of the incidence of non-AIDS cancers in HIV-infected individuals. J Acquir Immune Defic Syndr 2009;52:611-22.

73. Guiguet M, Boue F, Cadranel J, et al. Effect of immunodeficiency, HIV viral load, and antiretroviral therapy on the risk of individual malignancies (FHDHANRS CO4): a prospective cohort study. Lancet Oncol 2009;10:1152-9.

74. Mortaz E, Tabarsi P, Mansouri D, et al. Cancers Related to Immunodeficiencies: Update and Perspectives. Front Immunol 2016;7:365.

75. Ferrara JL, Levine JE, Reddy P, et al. Graft-versus-host disease. Lancet 2009;373:1550-61.

76. Akahoshi M, Takanashi M, Masuda M, et al. A case of transfusion-associated graft-versus-host disease not prevented by white cell-reduction filters. Transfusion 1992;32:169-72.

77. Hayashi H, Nishiuchi T, Tamura H, et al. Transfusion-

Cite this article as: Cho S, Park J, Lee M, Lee D, Choi H, Gim G, Kim L, Kang CY, Oh Y, Viveiros P, Vagia E, Oh MS, Cho GJ, Bharat A, Chae YK. Blood transfusions may adversely affect survival outcomes of patients with lung cancer: a systematic review and meta-analysis. Transl Lung Cancer Res 2021;10(4):1700-1710. doi: 10.21037/tlcr-20-933 associated graft-versus-host disease caused by leukocytefiltered stored blood. Anesthesiology 1993;79:1419-21.

78. van de Watering LM, Brand A, Houbiers JG, et al. Perioperative blood transfusions, with or without allogeneic leucocytes, relate to survival, not to cancer recurrence. Br J Surg 2001;88:267-72.

79. Jensen LS, Puho E, Pedersen L, et al. Long-term survival after colorectal surgery associated with buffy-coat-poor and leucocyte-depleted blood transfusion: a follow-up study. Lancet 2005;365:681-2.

80. Skånberg J, Lundholm K, Haglind E. Effects of blood transfusion with leucocyte depletion on length of hospital stay, respiratory assistance and survival after curative surgery for colorectal cancer. Acta Oncol 2007;46:1123-30.

81. Lange MM, van Hilten JA, van de Watering LM, et al. Leucocyte depletion of perioperative blood transfusion does not affect long-term survival and recurrence in patients with gastrointestinal cancer. Br J Surg 2009;96:734-40.

82. Hjalgrim H, Edgren G, Rostgaard K, et al. Cancer incidence in blood transfusion recipients. J Natl Cancer Inst 2007;99:1864-74.

83. Riedl R, Engels EA, Warren JL, et al. Blood transfusions and the subsequent risk of cancers in the United States elderly. Transfusion 2013;53:2198-206.

84. Skånberg J, Frisk B. Blood transfusion does not influence the development of malignant tumours. Eur J Surg 1999;165:528-34.

85. Cho GJ, Oh MS, Oh MJ, et al. Peripartum Blood Transfusions are Associated with Increased Risk of Cancer: A National Retrospective Cohort Study. Clin Epidemiol 2020;12:659-66.

86. Tabutin M, Couraud S, Guibert B, et al. Completion pneumonectomy in patients with cancer: postoperative survival and mortality factors. J Thorac Oncol 2012;7:1556-62. 
Table S1 Search strategy

\begin{tabular}{|c|c|c|c|c|c|}
\hline \multicolumn{3}{|c|}{ PubMed* } & \multicolumn{3}{|c|}{ Embase $^{\dagger}$} \\
\hline$\# 7$ & $\# 1$ and \#2 and \#3 and \#6 & 172 & $\# 7$ & $\# 1$ and \#2 and \#3 and \#6 & 323 \\
\hline$\# 6$ & \#4 or \#5 & $1,102,230$ & \#6 & \#4 or \#5 & $1,654,778$ \\
\hline$\# 5$ & 'recurrence' & 276,600 & $\# 5$ & 'recurrence' & 428,270 \\
\hline$\# 4$ & 'survival' & 898,717 & $\# 4$ & 'survival' & $1,345,136$ \\
\hline$\# 3$ & 'lung' & 588,171 & $\# 3$ & 'lung' & 870,940 \\
\hline$\# 2$ & 'cancer' & $1,635,186$ & \#2 & 'cancer' & $2,338,942$ \\
\hline$\# 1$ & 'transfusion' & 93,783 & $\# 1$ & 'transfusion' & 152,681 \\
\hline \multicolumn{3}{|c|}{ Cochrane Library ${ }^{\ddagger}$} & \multicolumn{3}{|c|}{ Ovid MEDLINE ${ }^{\S}$} \\
\hline$\# 7$ & $\# 1$ and \#2 and \#3 and \#6 & 198 & $\# 7$ & $\# 1$ and \#2 and \#3 and \#6 & 150 \\
\hline$\# 6$ & \#4 or \#5 & 149,915 & \#6 & \#4 or \#5 & 956,243 \\
\hline$\# 5$ & 'recurrence' & 66,742 & \#5 & 'recurrence' & 236,012 \\
\hline$\# 4$ & 'survival' & 103,373 & $\# 4$ & 'survival' & 782,513 \\
\hline$\# 3$ & 'lung' & 66,911 & $\# 3$ & 'lung' & 509,846 \\
\hline$\# 2$ & ‘cancer' & 152,653 & $\# 2$ & ‘cancer' & $1,379,773$ \\
\hline$\# 1$ & 'transfusion' & 16,026 & $\# 1$ & 'transfusion' & 79,191 \\
\hline
\end{tabular}

*, search options to limit the results to title or abstract were used as follows: ([Title/Abstract]); ${ }^{\dagger}$, search options to limit the results to abstract or title were used as follows: (“:ab,ti”); ${ }^{\ddagger}$, search options to limit the results to title, abstract, or keyword were used as follows: (“:ti,ab,kw”); ${ }^{\S}$, search options to limit the results to abstract or title were used as follows: (“.ab,ti.").

Table S2 The Newcastle-Ottawa Quality Assessment Scale for cohort studies

\begin{tabular}{|c|c|c|c|c|c|c|c|c|c|}
\hline Study & & & & & Compa & rability & & Outrome & \\
\hline First Author (Near) & $\begin{array}{l}\text { Representattveness } \\
\text { of the exposed cothort }\end{array}$ & $\begin{array}{c}\text { Selection of the } \\
\text { non exposed ohthrt }\end{array}$ & $\begin{array}{l}\text { Ascertainment } \\
\text { of Expossure }\end{array}$ & $\begin{array}{l}\text { Demonstration that } \\
\text { outcome of of tinterest } \\
\text { was not pesent } \\
\text { at start of study }\end{array}$ & \begin{tabular}{|l} 
Study ontrols for the \\
mrost important factor
\end{tabular} & $\begin{array}{l}\text { Study ontrols for } \\
\text { any additional factor }\end{array}$ & $\begin{array}{l}\text { assessment } \\
\text { of outcoome }\end{array}$ & $\begin{array}{l}\text { Long gnough } \\
\text { Follow-up for } \\
\text { outcomes to ocaur }\end{array}$ & $\begin{array}{l}\text { Adequacy of } \\
\text { follow-up of cothorts }\end{array}$ \\
\hline Tartter (1984) & $\star$ & $\star$ & $\star$ & $\star$ & $\star$ & $\star$ & & $\star$ & $\star$ \\
\hline Hyman (1984) & $\star$ & $\star$ & $\star$ & $\star$ & * & & $\star$ & $\star$ & \\
\hline Pastorino (1986) & $\star$ & $\star$ & $\star$ & $\star$ & $\star$ & $\star$ & & $\star$ & \\
\hline Keller (1988) & $\star$ & $\star$ & $\star$ & $\star$ & $\star$ & $\star$ & $\star$ & $\star$ & $\star$ \\
\hline Moores (1989) & $\star$ & $\star$ & $\star$ & $\star$ & $\star$ & & & $\star$ & \\
\hline Lutte (1990) & $\star$ & $\star$ & $\star$ & $\star$ & $\star$ & & & $\star$ & $\star$ \\
\hline Pena (1992) & $\star$ & $\star$ & $\star$ & $\star$ & $\star$ & $\star$ & $\star$ & $\star$ & \\
\hline Zimmermann (1993) & $\star$ & $\star$ & $\star$ & $\star$ & $\star$ & & & $\star$ & \\
\hline Piantachsi (1994) & $\star$ & $\star$ & $\star$ & $\star$ & $\star$ & & & $\star$ & \\
\hline Rainio (1996) & $\star$ & $\star$ & $\star$ & $\star$ & $\star$ & $\star$ & & $\star$ & \\
\hline Casanova Vúdezz (1999) & $\star$ & $\star$ & $\star$ & $\star$ & $\star$ & & & $\star$ & $\star$ \\
\hline Nosotti (2003) & $\star$ & $\star$ & $\star$ & $\star$ & $\star$ & $\star$ & $\star$ & $\star$ & $\star$ \\
\hline Reyman (2003) & $\star$ & $\star$ & $\star$ & $\star$ & $\star$ & $\star$ & $\star$ & $\star$ & * \\
\hline Ghosh (2004) & $\star$ & $\star$ & $\star$ & $\star$ & $\star$ & $\star$ & $\star$ & $\star$ & $\star$ \\
\hline Peñalver (2005) & $\star$ & $\star$ & $\star$ & $\star$ & $\star$ & $\star$ & & $\star$ & $\star$ \\
\hline Berardi (2005) & $\star$ & $\star$ & $\star$ & $\star$ & $\star$ & $\star$ & & $\star$ & \\
\hline Thomas (2007) & $\star$ & $\star$ & $\star$ & $\star$ & $\star$ & $\star$ & $\star$ & $\star$ & $\star$ \\
\hline Chen (2007) & $\star$ & $\star$ & $\star$ & $\star$ & $\star$ & $\star$ & $\star$ & $\star$ & \\
\hline Panagopouths (2008) & $\star$ & $\star$ & * & $\star$ & * & $\star$ & & $\star$ & $\star$ \\
\hline Ng (2012) & $\star$ & $\star$ & $\star$ & $\star$ & $\star$ & $\star$ & $\star$ & $\star$ & \\
\hline Cata (2013) & 夫 & $\star$ & $\star$ & $\star$ & * & $\star$ & & $\star$ & \\
\hline Latif (2019) & $\star$ & $\star$ & $\star$ & $\star$ & $\star$ & $\star$ & $\star$ & $\star$ & \\
\hline Sakin (2019) & $\star$ & $\star$ & $\star$ & $\star$ & $\star$ & $\star$ & & $\star$ & \\
\hline
\end{tabular}




\section{NEWCASTLE - OTTAWA QUALITY ASSESSMENT SCALE COHORT STUDIES}

Note: A study can be awarded a maximum of one star for each numbered item within the Selection and Outcome categories. A maximum of two stars can be given for Comparability

\section{Selection}

1) Representativeness of the exposed cohort

a) truly representative of the average

b) somewhat representative of the average

c) selected group of users eg nurses, volunteers

d) no description of the derivation of the cohort

(describe) in the community

Selection of the non exposed cohort

a) drawn from the same community as the exposed cohort

b) drawn from a different source

c) no description of the derivation of the non exposed cohort

3) Ascertainment of exposure

a) secure record (eg surgical records)

b) structured interview

c) written self report

d) no description

4) Demonstration that outcome of interest was not present at start of study

a) yes *

b) no

\section{Comparability}

1) Comparability of cohorts on the basis of the design or analvsis

a) study controls for (select the most important factor) *

b) study controls for any additional factor * (This criteria could be modified to indicate specific control for a second important factor.)

\section{Outcome}

1) Assessment of outcome

a) independent blind assessment

b) record linkage *

c) self report

d) no description

2) Was follow-up long enough for outcomes to occur

a) yes (select an adequate follow up period for outcome of interest)

b) no

3) Adequacy of follow up of cohorts

a) complete follow up - all subjects accounted for *

b) subjects lost to follow up unlikely to introduce bias - small number lost - >

adequate \%) follow up, or description provided of those lost) *

c) follow up rate $<\ldots \%$ (select an adequate \%) and no description of those lost

d) no statement

Table S3 Characteristics of excluded studies

\begin{tabular}{|c|c|c|c|c|}
\hline First Author & Year & Title & Journal & Reason for exclusion \\
\hline Bickel & 1985 & Effect of blood transfusions on survival after cancer surgery & Neth J Med & No outcome of interest \\
\hline Keller & 1989 & Blood transfusion and lung cancer recurrence & Ann Thorac Surg & Correspondence \\
\hline Wu & 1989 & $\begin{array}{l}\text { Influence of blood transfusion on postoperative prognosis of } \\
\text { stage I (NO) lung cancer }\end{array}$ & $\begin{array}{l}\text { Zhonghua Zhong Liu } \\
\text { Za Zhi }\end{array}$ & No outcome of interest \\
\hline Genetet & 1991 & Incidence of blood transfusion on the development of cancer & Presse Med & Review \\
\hline Ford & 1994 & Transfusion and second malignancy & Transfusion & No outcome of interest \\
\hline Novak & 1994 & $\begin{array}{l}\text { Survival after surgery for bronchogenic carcinoma in relation to } \\
\text { blood transfusion }\end{array}$ & Rozhl Chir & No outcome of interest \\
\hline Vamvakas & 1995 & $\begin{array}{l}\text { Perioperative blood transfusion and cancer recurrence: } \\
\text { meta-analysis for explanation }\end{array}$ & Transfusion & Review \\
\hline Wang & 1999 & $\begin{array}{l}\text { The effect of perioperative blood transfusion on survival in lung } \\
\text { cancer }\end{array}$ & $\begin{array}{l}\text { Zhong Guo Chang } \\
\text { Kuang Yi Xue }\end{array}$ & No outcome of interest \\
\hline Mizianty & 2002 & $\begin{array}{l}\text { Homologous blood transfusion and survival after surgery in } \\
\text { patients with squamous cell lung cancer }\end{array}$ & Pol Przegl Chir & No outcome of interest \\
\hline Veikutiene & 2008 & Transfusion of autologous blood & Medicina (Kaunas) & Review \\
\hline Churchhouse & 2012 & $\begin{array}{l}\text { Does blood transfusion increase the chance of recurrence in } \\
\text { patients undergoing surgery for lung cancer? }\end{array}$ & $\begin{array}{l}\text { Interact Cardiovasc } \\
\text { Thorac Surg }\end{array}$ & Review \\
\hline Peeples & 2014 & $\begin{array}{l}\text { The Impact of Perioperative Transfusions on Cancer Recurrence } \\
\text { and Survival following Oncologic Resection [abstract] }\end{array}$ & Ann Surg Oncol & No outcome of interest \\
\hline Wang & 2014 & $\begin{array}{l}\text { Perioperative blood transfusion is associated with worse clinical } \\
\text { outcomes in resected lung cancer }\end{array}$ & Ann Thorac Surg & Review \\
\hline Luan & 2014 & $\begin{array}{l}\text { Perioperative blood transfusion adversely affects prognosis after } \\
\text { resection of lung cancer: a systemic review and a meta-analysis }\end{array}$ & BMC Surg & Review \\
\hline Velásquez & 2015 & Transfusions of blood products and cancer outcomes & $\begin{array}{l}\text { Rev Esp Anestesiol } \\
\text { Reanim }\end{array}$ & Review \\
\hline Femandez & 2018 & $\begin{array}{l}\text { Differential effects of operative complications on survival after } \\
\text { surgery for primary lung cancer }\end{array}$ & $\begin{array}{l}\text { J Thorac Cardiovasc } \\
\text { Surg }\end{array}$ & No outcome of interest \\
\hline
\end{tabular}

